\title{
ENHANCEMENT OF SOIL DNA EXTRACTION BY THE USE OF A HAND HELD MIXER
}

\author{
Jefferson Luis da Silva Costa*; Virgínia Carla de Oliveira \\ Laboratório Integrado de Biotecnologia, Fitopatologia e Microbiologia, EMBRAPA Tabuleiros Costeiros, Aracaju, SE, Brasil
}

Submitted: February 12, 2003; Approved: May 06, 2003

\section{SHORT COMMUNICATION}

\begin{abstract}
The efficiency of soil DNA extraction using a bead beater homogenizer (Biospec Products - Germany) was compared to that obtained with a hand held mixer (Moulinex - Brazil). The hand held mixer costs 100 times less and extracted seven times more crude DNA than the bead beater.
\end{abstract}

Key words: molecular tools, DNA extraction.

Several procedures have been useful in the evaluation of the microbial ecology in a specific environment. However, some of the methods present limitations regarding sensibility. The traditional technique of plating on agar media fail to recover many populations, since more than $90 \%$ of the microorganisms that inhabit the soil can not be cultivated (1). A new methodological approach of molecular genetics to monitor the environment has been developed. It requires the soil DNA extraction. Once DNA is extracted, other methodologies based on the PCR amplification of a conserved region of genes in different groups of microorganisms $(3,6)$ have been used to study soil diversity. For this reason, techniques for direct extraction of soil DNA have been tested and enhanced $(2,5)$. In this study, the efficiency of DNA extraction in four soil samples using two different protocols was evaluated. In one, a mini bead beater, developed by Biospec Products (Germany) as a cell homogenizer was used. In the other, a common household kitchen mixer, made by Moulinex (Brazil), was tested.

Soil samples from fields facing different levels of degradation were collected in a core of $10 \mathrm{~cm}$ depth and immediately frozen at $-70^{\circ} \mathrm{C}$. Genomic DNA was then extracted from soil samples following a modification of the method of Smalla et al. (5), using the mini-bead beater as well as the hand held mixer to induce cells lyses. Four grams from each soil sample were suspended in $4 \mathrm{ml}$ of $0.12 \mathrm{~mol}^{-1}$ phosphate buffer ( $\mathrm{pH} 8.0$ ). The resulting suspensions were shaken for $5 \mathrm{~min}$ at room temperature and incubated at $4^{\circ} \mathrm{C}$ for $30 \mathrm{~min}$. After incubation, $480 \mathrm{~mL}$ of $20 \%$ duodecil sodium sulphate (SDS) was added and suspensions were kept on ice. From this point on, the buffer used in the mini bead beater was amended with $0.8 \mathrm{~g}$ of glass beads $(0.1 \mathrm{~mm}$ diameter), and the buffer used for the hand held mixer was supplemented with lysozyme (Sigma, Co.) at a final concentration of $5 \mathrm{mg} \mathrm{mL}^{-1}$. In both methods the mixtures were shaken three times for $90 \mathrm{~s}$. at the highest speed and then were centrifuged at $14,000 \mathrm{~g}$ at room temperature. The resulting suspensions were submitted to the same extraction procedures described by Smalla et al. (5). The crude DNA preparations were then subjected to two sequential cleaning steps: cesium chloride $(\mathrm{CsCl})$ and potassium acetate $(\mathrm{Kac})(4)$. A final wizard spin column (Wizard DNA clean-Up System, Promega, Madison, WI, USA) purification was performed according to the manufacturer's instructions. The DNA obtained by using both methods was quantified in a fluorometer and also estimated on $1.5 \%$ agarose gel, stained with ethidium bromide and photographed with an Eagle Eye System (Stratagene). The Gibco-BRL 100 bp ladder was used to determine the sizes of the fragments. The amount of DNA recovered in the crude preparations by cells lyses induced in the mini bead beater resulted in 0.5 to $1.0 \mathrm{mg}$ of DNA

*Corresponding author. Mailing address: EMBRAPA Tabuleiros Costeiros. Av. Beira Mar, 3250. Caixa Postal 44. 49025-040, Aracaju, SE, Brasil. Tel.: (+5579) 226-1300. Fax: (+5579) 226-1369. E-mail: jcosta@cpatc.embrapa.br 


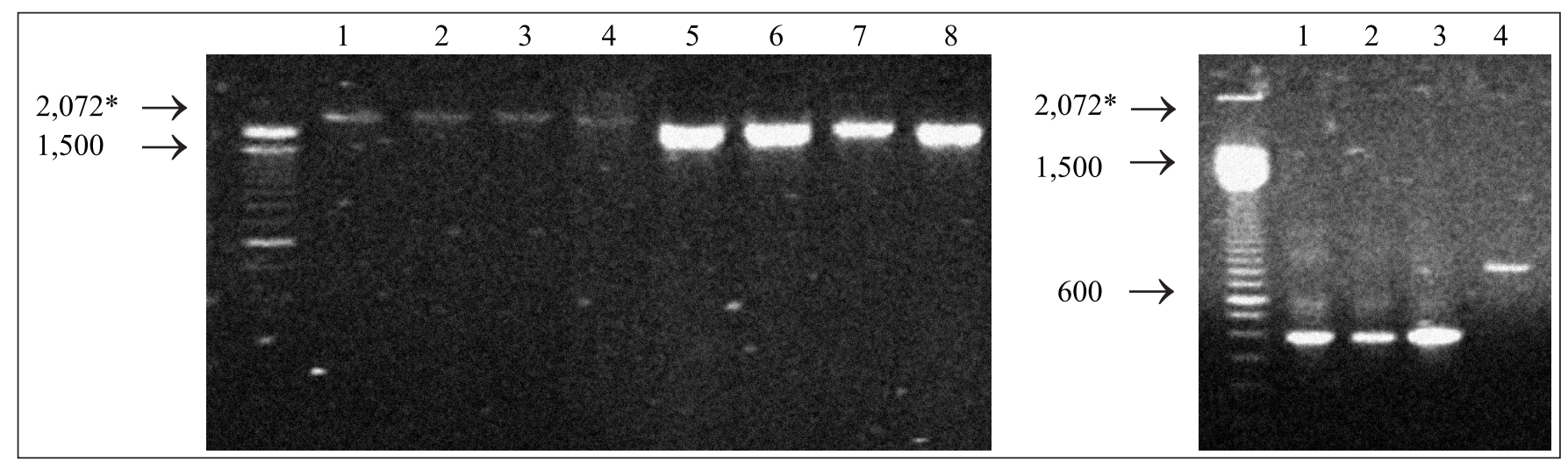

Figure 1.A: DNA (10 mL sample per well) obtained from 4 soil samples by using two procedures. Lanes 1 - 4: DNA extracted with a mini bead beater; Lanes 5-8: DNA extracted with a hand held mixer; B: Polimerase reaction (PCR) products of amplified soil DNA extracted with a hand held mixer. Lanes 1-2-3: amplification of the nuclear 28S subunit rDNA gene; Lane 4: amplification of the nuclear 18S subunit rDNA gene. * Fragments size (100 bp, Gibco-BRL, Gaithersburg, MD, USA).

per gram of soil. The cells lyses induced by the hand held mixer resulted in a considerable improvement of DNA recovery, i.e. from 5.0 to $7.5 \mathrm{mg}$ of DNA per gram of soil (Figs. 1 and 2). It was also tested if the DNA yielded by the hand held mixer was clean enough to be amplifiable. For this reason the DNA extraction products obtained by using the hand held mixer were submitted to a PCR amplification of the nuclear $18 \mathrm{~S}$ and $28 \mathrm{~S}$ small-subunit rDNA according to standard protocols $(3,6)$. The products were successfully amplified generating around $400 \mathrm{bp}$ for $28 \mathrm{~S}$ region and $950 \mathrm{bp}$ for $18 \mathrm{~S}$ region (Fig. 1). This procedure is a reliable, simple and affordable for enhancement of crude soil DNA extraction. The DNA extracted by using the hand held mixer yielded higher amounts of pure DNA and it accounts for a 100 times less the cost of the mini bead beater.

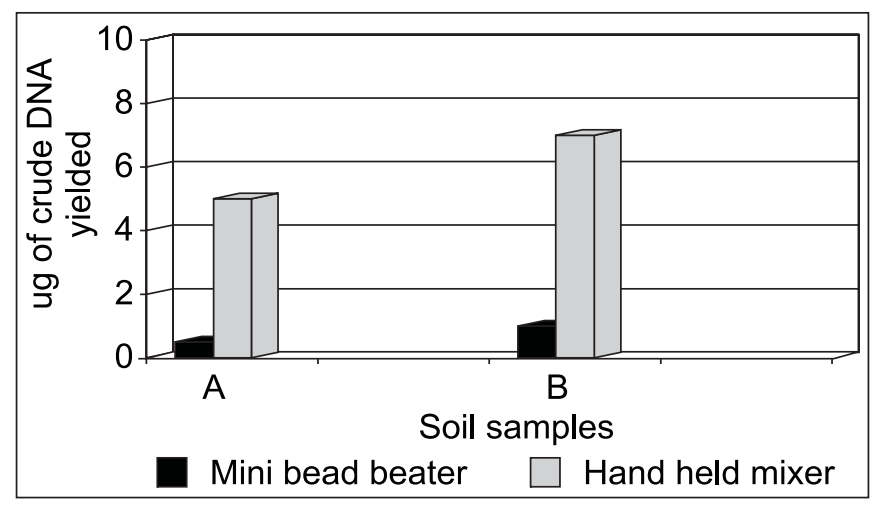

Figure 2. Amount of DNA yielded by the two extraction methods: a hand held mixer and the mini bead beater.

\section{RESUMO}

\section{Otimização da extração de DNA do solo utilizando um homogeneizador manual}

A eficiência da extração de DNA do solo utilizando um homogeneizador bead beater (Biospec Products - Alemanha) foi comparada àquela obtida utilizando um homogeneizador manual (Moulinex - Brasil). O homogeneizador manual tem custo 100 vezes menor e revelou-se mais eficiente que o bead beater extraindo sete vezes mais DNA.

Palavras-chave: ferramentas moleculares, extrato de DNA

\section{REFERENCES}

1. Holben, W.E.; Janson, J.K.; Chelm, B.K.; Tiedje, J.M. DNA probe method for the detection of specific microorganisms in the soil bacterial community. Appl. Envir. Microbiol., 54:703-711, 1988.

2. Hugenholtz, P.; Pace, N.R. Identifying microbial diversity in the natural environment: a molecular phylogenetic approach. Trends. Biotechnol., 6:190-197, 1996.

3. Lane, D.L.; Pace, B.; Oisen, G.J.; Stahl, D.A.; Sogin, M.L.; Pace, N.R. Rapid determination of $16 \mathrm{~S}$ ribosomal RNA sequences for phylogenetic analysis. Proc. Nat. Acad. Sci., 82:6955-6959, 1985.

4. Ogram, A.; Sayler, G.S.; Barkay, T.J. DNA extraction and purification from sediments. J. Microbiol. Meth., 7:57-66, 1987.

5. Smalla, K.; Cresswell, N.; Mendonça-Hagler, L.C.; Wolters, A.C.; Can Elsas, J.D. Rapid DNA extraction protocol from soil for polymerase chain reaction-mediated amplification. J. Appl. Bacteriol., 74:78-85, 1993.

6. Smit, E.; Leeflang, P.; Glandorf, B.; Elsas, J.D. Van; Wernars, K. Analysis of fungal diversity in the wheat rhizosphere by sequencing of cloned PCR-amplified genes encoding 18S rRNA and temperature gradient gel eletrophoresis. App. Environ. Microbiol., 65:2614-2621, 1999. 